\title{
Roflumilast attenuates allergen-induced inflammation in mild asthmatic subjects
}

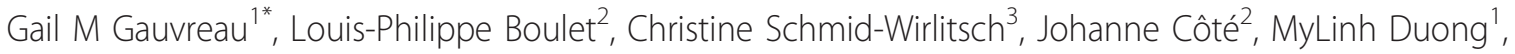 \\ Kieran J Killian', Joanne Milot², Francine Deschesnes ${ }^{2}$, Tara Strinich', Richard M Watson', Dirk Bredenbröker ${ }^{3}$ and \\ Paul M O'Byrne ${ }^{1}$
}

\begin{abstract}
Background: Phosphodiesterase 4 (PDE4) inhibitors increase intracellular cyclic adenosine monophosphate (CAMP), leading to regulation of inflammatory cell functions. Roflumilast is a potent and targeted PDE4 inhibitor. The objective of this study was to evaluate the effects of roflumilast on bronchoconstriction, airway hyperresponsiveness (AHR), and airway inflammation in mild asthmatic patients undergoing allergen inhalation challenge.
\end{abstract}

Methods: 25 subjects with mild allergic asthma were randomized to oral roflumilast 500 mcg or placebo, once daily for 14 days in a double-blind, placebo-controlled, crossover study. Allergen challenge was performed on Day 14, and FEV 1 was measured until $7 \mathrm{~h}$ post challenge. Methacholine challenge was performed on Days 1 (pre-dose), 13 (24 h pre-allergen), and 15 (24 h post-allergen), and sputum induction was performed on Days 1, 13, 14 (7 h post-allergen), and 15.

Results: Roflumilast inhibited the allergen-induced late phase response compared to placebo; maximum \% fall in $\mathrm{FEV}_{1}$ $(p=0.02)$ and the area under the curve $(p=0.01)$. Roflumilast had a more impressive effect inhibiting allergen-induced sputum eosinophils, neutrophils, and eosinophil cationic protein (ECP) at $7 \mathrm{~h}$ post-allergen (all $\mathrm{p}=0.02$ ), and sputum neutrophils $(p=0.04)$, ECP $(p=0.02)$, neutrophil elastase $(p=0.0001)$ and AHR $(p=0.004)$ at 24 h post-allergen.

Conclusions: This study demonstrates a protective effect of roflumilast on allergen-induced airway inflammation. The observed attenuation of sputum eosinophils and neutrophils demonstrates the anti-inflammatory properties of PDE4 inhibition and supports the roles of both cell types in the development of late phase bronchoconstriction and AHR.

Trial Registration: ClinicalTrials.gov: NCT01365533

Keywords: Allergic asthma, allergen challenge, PDE4 inhibitor, inflammation, sputum, neutrophils, eosinophils

\section{Background}

Asthma is characterized by the presence of cough, wheeze, dyspnea, reversible airway obstruction and airway hyperresponsiveness. Eosinophils are cells recognized to be a key feature of allergic asthma [1], however patients with severe asthma have increases in both eosinophils and neutrophils in their sputum [2]. Furthermore, severe asthma exacerbations are associated with bronchial mucosal eosinophilia and neutrophilia, as well as upregulation of CXC chemoattractants and their receptors [3]. Although current asthma

\footnotetext{
* Correspondence: gauvreau@mcmaster.ca

'Department of Medicine, McMaster University, Hamilton, Ontario, Canada Full list of author information is available at the end of the article
}

therapies such as corticosteroids are effective in inhibiting eosinophilic inflammation through Th2 suppression, they may enhance neutrophil accumulation into the airways and until now therapies that effectively suppress neutrophilic inflammation have been lacking $[4,5]$.

The intracellular signalling molecules, cyclic adenosine monophosphate (cAMP) and cyclic guanosine monophosphate (cGMP), are implicated in the pathophysiology of asthma; they promote smooth muscle relaxation and inhibit inflammation [6]. A novel approach for therapeutic intervention in asthma is through regulation of the phosphodiesterase (PDE) activity, which is the only cellular pathway available for degradation of cAMP and

\section{() Biomed Central}


cGMP [7]. Roflumilast has been shown to improve lung function and reduce exacerbations in chronic obstructive pulmonary disease (COPD) [8,9] and has recently been approved in the EU and Canada for oral once-daily treatment of severe COPD.

Roflumilast is a selective inhibitor of the PDE4 isoform which is specific for cAMP degradation, and is expressed in several effector cells central to the pathophysiology of asthma including eosinophils, neutrophils and lymphocytes $[10,11]$. As a significant increase in PDE4 activity has been reported in patients with asthma or allergy compared with healthy individuals $[12,13]$, it is therefore of interest to explore PDE4 inhibition as a potential therapeutic option for treatment of atopic asthma, given the proposed anti-inflammatory mode of action [14].

Subjects with allergic asthma develop an immediate IgEmediated early asthmatic response (EAR) following inhalation of a sufficient dose of an allergen to which they are sensitized [15]. Up to $50 \%$ of these subjects also develop a late asthmatic response (LAR) beginning 3 to 4 hours after allergen inhalation challenge [16], and an associated elevation in levels of eosinophils, basophils and mast cells, other effector cells including $\mathrm{T}$ lymphocytes [17-20], and Th2-related cytokines and chemokines [18,20-22]. Roflumilast is a potent and targeted PDE4 inhibitor, approved by the European Commission as an add-on to bronchodilator therapy for the treatment of severe chronic obstructive pulmonary disease (COPD) associated with chronic bronchitis in adults with a history of frequent exacerbations, and targets the underlying inflammation in COPD. We hypothesized that roflumilast would attenuate allergen-induced LAR and airway hyperresponsiveness (AHR) through inhibition of airway inflammation. Some of the results of this study have been previously reported in the form of an abstract [23].

\section{Methods}

\section{Subjects}

Forty-seven non-smoking subjects with mild atopic stable asthma underwent screening for this study. Subjects were required to have a forced expiratory volume in one second $\left(\mathrm{FEV}_{1}\right) \geq 70 \%$ of predicted and baseline methacholine $\mathrm{PC}_{20}$ (the provocative concentration of methacholine causing a $20 \%$ fall in $\left.\mathrm{FEV}_{1}\right) \leq 16 \mathrm{mg} / \mathrm{mL}$. Subjects had no other lung disease, no lower respiratory tract infection or worsening of asthma for 6 weeks before screening, and avoided exposure to sensitizing allergens apart from house dust mite. Subjects were steroid-naïve and used infrequent

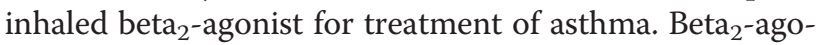
nist and caffeinated beverages were withheld for at least $8 \mathrm{~h}$ before laboratory visits. Twenty-five subjects, $10 \mathrm{male} /$ 15 female, aged 18-54 years old (Table 1) met all criteria including the development of allergen-induced EAR and LAR. EAR was defined by an acute fall in $\mathrm{FEV}_{1} \geq 20 \%$
Table 1 Mean subject demographics and baseline characteristics (range)

\begin{tabular}{cc}
\hline Parameter & $\begin{array}{c}\text { Intent to treat population } \\
\mathbf{N}=\mathbf{2 5}\end{array}$ \\
\hline Age, years & $28.7(18-54)$ \\
\hline Gender, males/females & $10 / 15$ \\
\hline History of asthma, years & $15.3(0-43)$ \\
\hline FEV $1 \%$ predicted & $92.8(75.9-117.1)$ \\
\hline Methacholine PC $_{20}, \mathrm{mg} / \mathrm{ml}$ & $4.0(0.3-14.4)$ \\
\hline Smokers & none
\end{tabular}

Legend: $\mathrm{FEV}_{1}$ : forced expiratory volume in 1 second; $\mathrm{PC}_{20}$ : provocative concentration causing a $20 \%$ fall in $\mathrm{FEV}_{1}$.

within $2 \mathrm{~h}$ following allergen challenge, and LAR was defined by a fall in $\mathrm{FEV}_{1} \geq 15 \%$ between $3 \mathrm{~h}$ and $7 \mathrm{~h}$ following allergen challenge.

\section{Study Design}

This trial was a two-center, double-blind, randomized, placebo-controlled, cross-over study, comparing 14 days treatment with roflumilast, $500 \mathrm{mcg}$, with placebo (Figure 1). The primary outcome was the effect of roflumilast on allergen-induced airway eosinophilia. Secondary outcomes were the allergen-induced EAR, LAR, AHR, steady-state pharmacokinetics $(\mathrm{PK})$ of roflumilast and roflumilast $\mathrm{N}$-oxide, safety and tolerability of roflumilast, and allergen-induced airway metachromatic cells (MCC) and airway inflammatory cell mediator levels. The study was registered with http://clinicaltrials.govNCT01365533.

The study was carried out from December 2004 to July 2005. Each site was given a block of kits containing drug and placebo. The randomization code was computer-generated, and eligible subjects were assigned the next available kit at the site by study staff. All subjects and trial staff remained blinded to the random order during the trial.

The study was approved by the ethics research board of the respective institutions, and signed informed consent of all subjects was obtained. Screening of subjects was performed over 1 week and included 3 consecutive days for assessment of responses to inhaled allergen challenge (Figure 1). Those who developed a fall in $\mathrm{FEV}_{1}$ of $\geq 20 \%$ within $2 \mathrm{~h}$ post allergen (EAR), and $\geq 15 \%$ between 3 and $7 \mathrm{~h}$ post allergen (LAR) were randomized to two treatment periods separated by 3-5 weeks. To enter a treatment period, methacholine $\mathrm{PC}_{20}$ was required to be within one doubling dose of that measured during screening, and $\mathrm{FEV}_{1} \geq 70 \%$ of predicted. Methacholine challenge and sputum induction were performed in the morning of Day 1 (before dosing), Day 13 (24 h pre allergen challenge), and Day 15 (24 h post allergen challenge). Allergen challenge was performed on the morning of Day 14 , and sputum was induced $7 \mathrm{~h}$ post allergen challenge. 


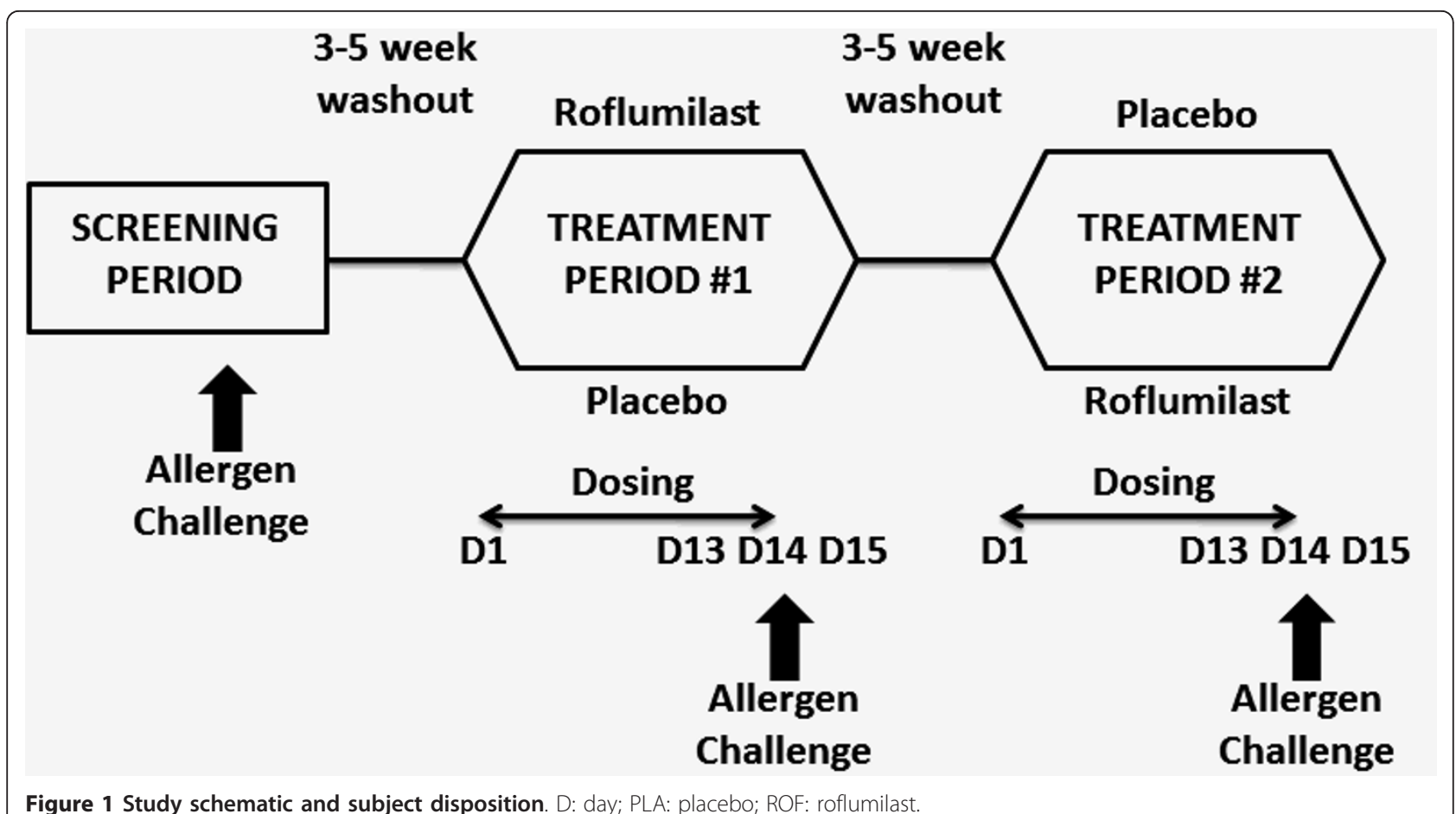

Blood was collected for pharmacokinetics throughout Day 14.

\section{Laboratory Procedures \\ Study Medication}

Patients received one roflumilast 500 mcg or placebo tablet orally each morning after breakfast (taken with at least $200 \mathrm{~mL}$ of fluid) for 14 consecutive days. The first dose of study drug was administered in the laboratory after all study procedures were completed. Subjects selfadministered the study drug from Day 2 to Day 12 . Doses on Days 13 and 14 were administered in the laboratory approximately 15 minutes before study procedures. Roflumilast $500 \mathrm{mcg}$ was selected because it is well tolerated and effective in asthma control at this dose [24].

\section{Methacholine Inhalation Challenge}

Methacholine $\mathrm{PC}_{20}$ was measured as described by Cockcroft [25] using tidal breathing from a Wright nebulizer. The test was terminated when a fall in $\mathrm{FEV}_{1}$ of at least $20 \%$ of the baseline value occurred.

\section{Allergen Inhalation Challenge}

$\mathrm{FEV}_{1}$ was required to be within $10 \%$ of baseline to proceed with the challenge. Allergen inhalation was performed as described by O'Byrne and colleagues [16] using the concentration of allergen extract determined from a formula described by Cockcroft and coworkers [26]. During the screening period, doubling concentrations of allergen were administered until $a \geq 20 \%$ fall in
$\mathrm{FEV}_{1}$ at 10 minutes post allergen was reached. $\mathrm{FEV}_{1}$ was then measured at regular intervals until $7 \mathrm{~h}$ after allergen inhalation. Only subjects developing a LAR of $\geq 15 \%$ fall in $\mathrm{FEV}_{1}$ during the screening period were eligible to participate in the study. All subjects inhaled the same dose of allergen for each of the two treatment periods. EAR was defined as the largest fall in $\mathrm{FEV}_{1}$ within $2 \mathrm{~h}$ after allergen challenge, and LAR was defined as the largest fall in $\mathrm{FEV}_{1}$ between $3 \mathrm{~h}$ and $7 \mathrm{~h}$ after allergen challenge. The early and late responses area under the curve (AUC) were calculated from $0-2 \mathrm{~h}$ and 3-7 h, respectively (AUC 0-2h, AUC 3-7h) by plotting the response using graphics software that calculated the area of the $\mathrm{FEV}_{1}$-time response and expressed as liters by hours (Lxh).

\section{Sputum Analysis}

Sputum was induced and processed using the method described by Pizzichini and co-workers [27]. The total cell count was determined using a Neubauer hemocytometer chamber (Hausser Scientific, Blue Bell, PA) and expressed as the number of cells per gram of sputum. Cells were prepared on 4 glass slides. Two slides were stained with Diff Quik (American Scientific Products, McGaw Park, IL) and duplicate differential counts ( 400 cells/slide) were averaged. Two slides were fixed in Carnoy's solution (60\% ethanol, 30\% chloroform and 10\% glacial acetic acid), stained with toluidine blue (Sigma-Aldrich, St. Louis,. $\mathrm{MO}$ ) which stains the nuclei of all cells pale blue, and glycosaminoglycan-containing granules in the cytoplasm of mast cells and basophils stain metachromatically red/ 
purple. Five thousand cells on each of the two slides were assessed for positive metachromatic staining, and expressed as the number of metachromatic cells per gram of sputum. Supernatant was stored at $-70^{\circ} \mathrm{C}$ and assayed in duplicate using commercial ELISAs for interleukin (IL)-8, myeloperoxidase and neutrophil elastase (R\&D Systems, Minneapolis, MN). Eosinophil cationic protein was measured using UniCap (Somagen Diagnostics, Edmonton, $\mathrm{AB})$.

\section{Pharmacokinetic Assessments}

Blood was collected from 15 subjects at one trial site for pharmacokinetic assessments on Day 14 of each treatment period. Blood was collected pre-dose and post-dose at $15 \mathrm{~min}, 30 \mathrm{~min}, 60 \mathrm{~min}, 90 \mathrm{~min}, 2 \mathrm{~h}, 3 \mathrm{~h}, 4 \mathrm{~h}, 6 \mathrm{~h}, 8 \mathrm{~h}$, $12 \mathrm{~h}$, and $24 \mathrm{~h}$. Venous blood was withdrawn into vacuum blood collection tubes containing lithium heparin, and plasma was separated within $30 \mathrm{~min}$ by centrifugation at $1000 \mathrm{~g}$ for $10 \mathrm{~min}$ in a refrigerated centrifuge. Plasma samples were frozen at $-20^{\circ} \mathrm{C}$ then assayed for roflumilast and roflumilast-N-oxide. Analytical measurements of roflumilast and roflumilast $\mathrm{N}$-oxide were performed by a validated method using high performance liquid chromatography (HPLC) coupled with tandem mass spectrometry (HPLCMS/MS) and allowed an LLOQ of $0.1 \mu \mathrm{g} / \mathrm{L}$ for both, roflumilast, and roflumilast $\mathrm{N}$-oxide using $0.4 \mathrm{~mL}$ human plasma.

\section{Statistical Analysis}

The per-protocol data were analyzed to accommodate the crossover design, thereby removing data from subjects not completing both study periods. Data are presented from 22 subjects as mean \pm standard error of the mean (SEM) unless otherwise noted. Methacholine $\mathrm{PC}_{20}$, sputum cell numbers and mediator levels were log-transformed prior to analyses. An ANCOVA adopted for the crossover design was performed to evaluate the effects of treatment and period; fixed factors were age, gender, value at the end of washout, and center. The random factor patient nested in sequence was included in the model. It was assumed that the random errors were independent and identically distributed with mean zero and equal variance.

\section{Results}

Two subjects withdrew prematurely from the study due to adverse events (depression, asthma), and one subject was excluded for using inhaled corticosteroids during the trial. Statistical analyses were carried out on the 22 subjects who completed the study per protocol. Baseline characteristics are shown in Table 1.

\section{Sputum Inflammatory Cells}

Roflumilast treatment had a significant effect on the total leukocyte count in sputum, thus cell populations are shown as absolute numbers rather than percentages.
After allergen inhalation, with placebo treatment, sputum eosinophils increased from a pre-allergen baseline of $28 \pm 6 / \mathrm{g}$ to $744 \pm 199 / \mathrm{g}$ at $7 \mathrm{~h}$ and $850 \pm 227 / \mathrm{g}$ at $24 \mathrm{~h}$ post-allergen (both $\mathrm{p}<0.0001$ ). Compared with placebo, roflumilast inhibited the allergen-induced increase in sputum eosinophils from a pre-allergen value of $29 \pm 12$ / $\mathrm{g}$ to $530 \pm 182 / \mathrm{g}$ at $7 \mathrm{~h}(\mathrm{p}=0.015)$ and $446 \pm 120 / \mathrm{g}(\mathrm{p}=$ 0.051 ) at $24 \mathrm{~h}$ post-allergen (Figure 2 ).

With placebo treatment, after allergen inhalation, sputum neutrophils increased from a pre-allergen baseline of $1.15 \pm 0.34 \times 10^{3} / \mathrm{g}$ to $4.13 \pm 0.1 .26 \times 10^{3} / \mathrm{g}$ and $4.56 \pm$ $0.1 .39 \times 10^{3} / \mathrm{g}$ at 7 and $24 \mathrm{~h}$ post-allergen (both $\mathrm{p}<$ 0.0001). Compared with placebo, roflumilast inhibited the allergen-induced increase in sputum neutrophils from $1.13 \pm 0.33 \times 10^{3} / \mathrm{g}$ pre-allergen to $1.66 \pm 0.32 \times 10^{3} / \mathrm{g}$ at $7 \mathrm{~h}$ and $1.61 \pm 0.38 \times 10^{3} / \mathrm{g}$ at $24 \mathrm{~h}$ post-allergen $(\mathrm{p}=$ 0.017 and $\mathrm{p}=0.04$, respectively) (Figure 2).

With placebo, allergen inhalation increased sputum MCC (basophils and mast cells) from a pre-allergen baseline of $1.0 \pm 1.0 / \mathrm{g}$ before challenge, to $10 \pm 4.0 / \mathrm{g}$ (p < $0.0001)$ at $7 \mathrm{~h}$, and $8.0 \pm 3.0 / \mathrm{g}(\mathrm{p}=0.002)$ at $24 \mathrm{~h}$ postallergen. Compared with placebo, roflumilast inhibited the allergen-induced increase in sputum MCC from pre-allergen value of $1.0 \pm 1.0 / \mathrm{g}$ before to $3.0 \pm 1.0 / \mathrm{g}$ and $4.0 \pm$ $2.0 / \mathrm{g}$ at 7 and $24 \mathrm{~h}$ post-allergen ( $\mathrm{p}=0.003$ and 0.37 , respectively) (Figure 2).

After 13 days of dosing, subjects receiving roflumilast had no change in baseline numbers of sputum eosinophils, neutrophils, or MCC (basophils and mast cells) (Figure 2).

\section{Sputum Fluid Phase Mediators}

The sputum supernatant was assayed for mediators associated with the activation and degranulation of eosinophils and neutrophils. With placebo treatment, the pre-allergen level of ECP rose significantly from $50.4 \pm$ $13.8 \mathrm{mcg} / \mathrm{mL}$ to $283.2 \pm 62.0 \mathrm{mcg} / \mathrm{mL}$ and $304.5 \pm 58.5$ $\mathrm{mcg} / \mathrm{mL}$ at $7 \mathrm{~h}$ and $24 \mathrm{~h}$ post-allergen $(\mathrm{p}<0.001)$. After roflumilast, this increase was attenuated from pre-allergen value of $45.5 \pm 15.0 \mathrm{mcg} / \mathrm{mL}$ to $178.2 \pm 57.6 \mathrm{mcg} /$ $\mathrm{mL}$ and $219.9 \pm 72.5 \mathrm{mcg} / \mathrm{mL}$ at $7 \mathrm{~h}$ and $24 \mathrm{~h}$ postallergen, respectively (both $\mathrm{p}<0.02$ ). The moderate increase in neutrophil elastase from $21.9 \pm 10.2 \mathrm{mcg} / \mathrm{mL}$ pre-allergen to $43.0 \pm 13.9 \mathrm{mcg} / \mathrm{mL}$ at $24 \mathrm{~h}$ post-allergen following placebo treatment was significantly attenuated by roflumilast, from $20.6 \pm 9.8 \mathrm{mcg} / \mathrm{mL}$ preallergen to $21.5 \pm 8.6 \mathrm{mcg} / \mathrm{mL}$ at $24 \mathrm{~h}$ post-allergen $(\mathrm{p}=0.0001)$. Post-allergen levels of myeloperoxidase and IL-8 were consistently lower with roflumilast treatment, however not statistically different than placebo (p > 0.05) (Figure 3).

After 13 days of dosing, subjects receiving roflumilast had no change in the level of ECP, IL-8, myeloperoxidate or neutrophil elastase (Figure 3). 

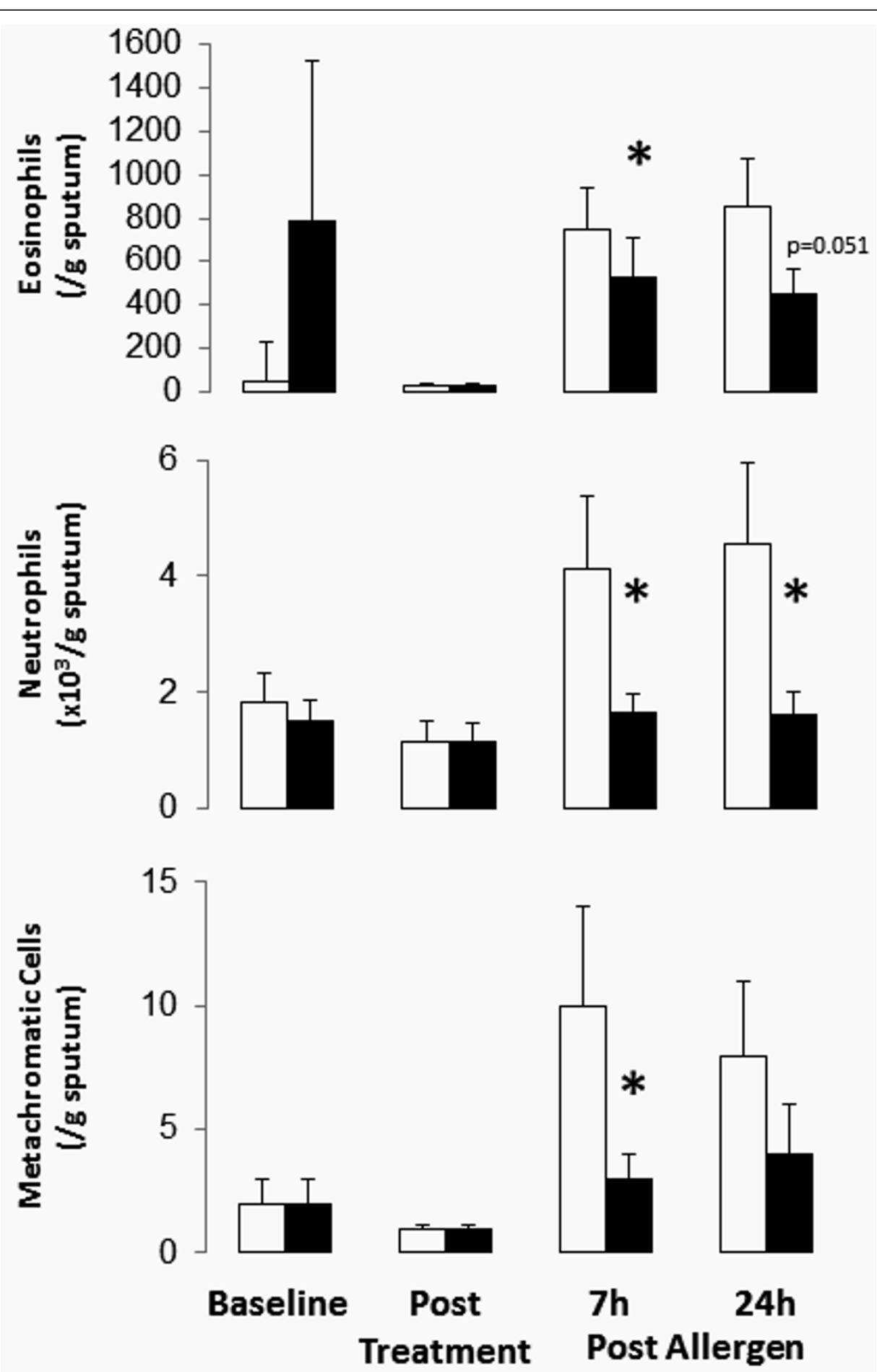

Figure 2 Mean sputum inflammatory cells $( \pm$ SEM) at baseline before treatment with roflumilast (solid bars) or placebo (open bars), after 13 days' treatment, and $7 \mathrm{~h}$ and $24 \mathrm{~h}$ after allergen challenge. Roflumilast significantly inhibited the allergen-induced influx of sputum eosinophils, neutrophils and metachromatic cells $(p<0.05)$.

\section{Allergen-Induced Airway Responses}

There was no difference in the baseline $\mathrm{FEV}_{1}$ after 14 days of treatment with roflumilast or placebo $(3.50 \pm 0.18 \mathrm{~L}$ vs $3.54 \pm 0.17 \mathrm{~L}$, respectively, $\mathrm{p}=0.28$. Both allergen-induced early and late falls in $\mathrm{FEV}_{1}$ were significantly inhibited by roflumilast (early AUC 0-2 h -0.78 \pm 0.10 Lxh compared to placebo $-0.94 \pm 0.12 \mathrm{Lxh},(\mathrm{p}=0.047)$ and late AUC 3-7 h $-1.19 \pm 0.25 \mathrm{Lxh}$ compared to placebo $-1.73 \pm 0.29 \mathrm{Lxh}$, 

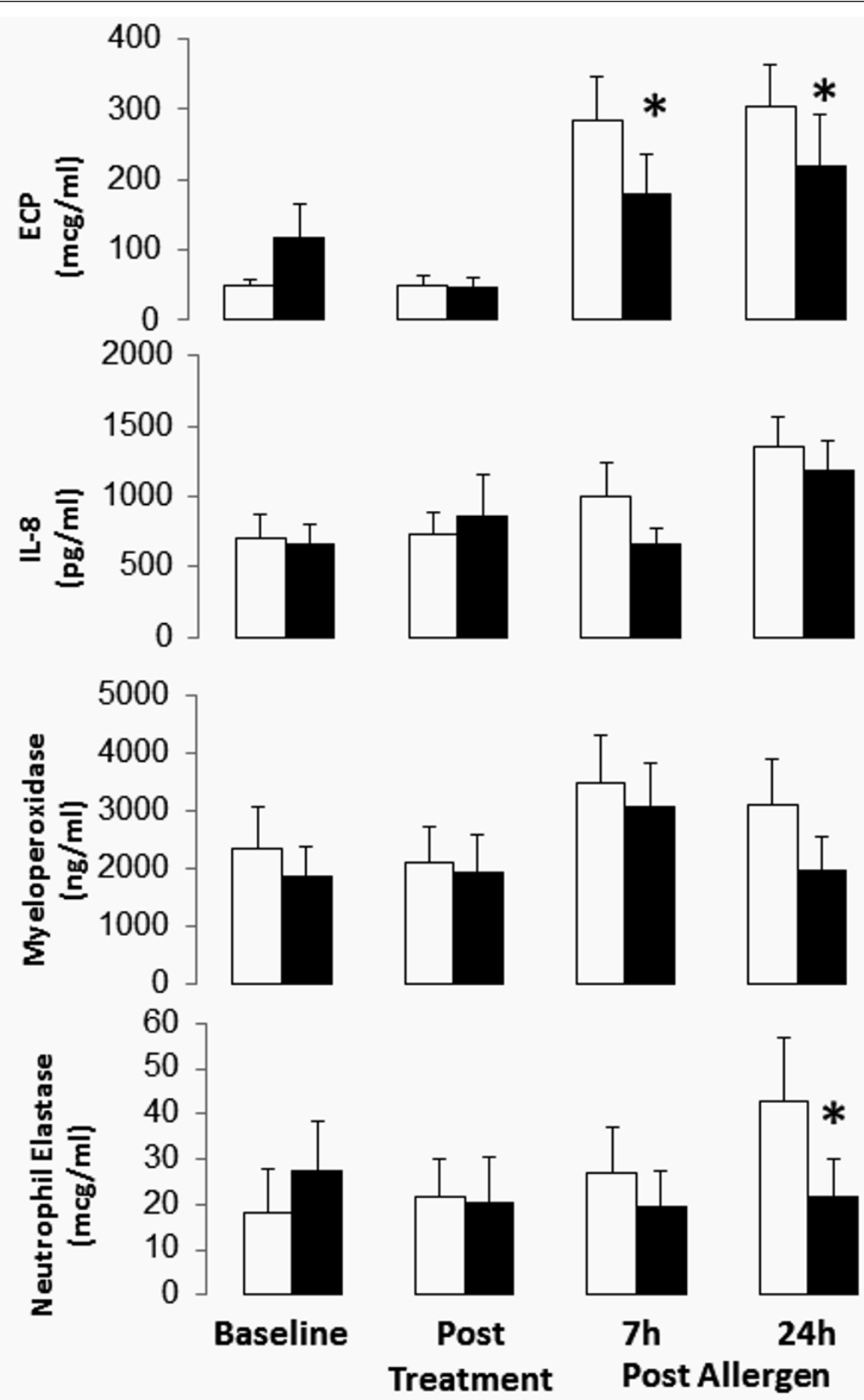

Figure 3 Mean sputum fluid phase mediators ( \pm SEM) at baseline before treatment with roflumilast (solid bars) or placebo (open bars), after 13 days' treatment, and $7 \mathrm{~h}$ and $24 \mathrm{~h}$ after allergen challenge. Roflumilast significantly inhibited the allergen-induced increased level of eosinophil cationic protein (ECP) and neutrophil elastase (NE) $(p<0.05)$.

$(\mathrm{p}=0.013)$. The maximum change in $\mathrm{FEV}_{1}$ during the early response was $-0.87 \pm 0.08 \mathrm{~L}(23.4 \%$ fall from baseline) with roflumilast compared to $-0.93 \pm 0.10 \mathrm{~L}(26.2 \%$ fall from baseline) with placebo $(\mathrm{p}=0.12)$. The maximum change in $\mathrm{FEV}_{1}$ during the late response was $-0.57 \pm 0.09$ $\mathrm{L}$ (16.2\% fall from baseline) with roflumilast compared to $-0.73 \pm 0.10 \mathrm{~L}$ ( $20.7 \%$ fall from baseline) with placebo $(\mathrm{p}=$ 0.02) (Figure 4). 


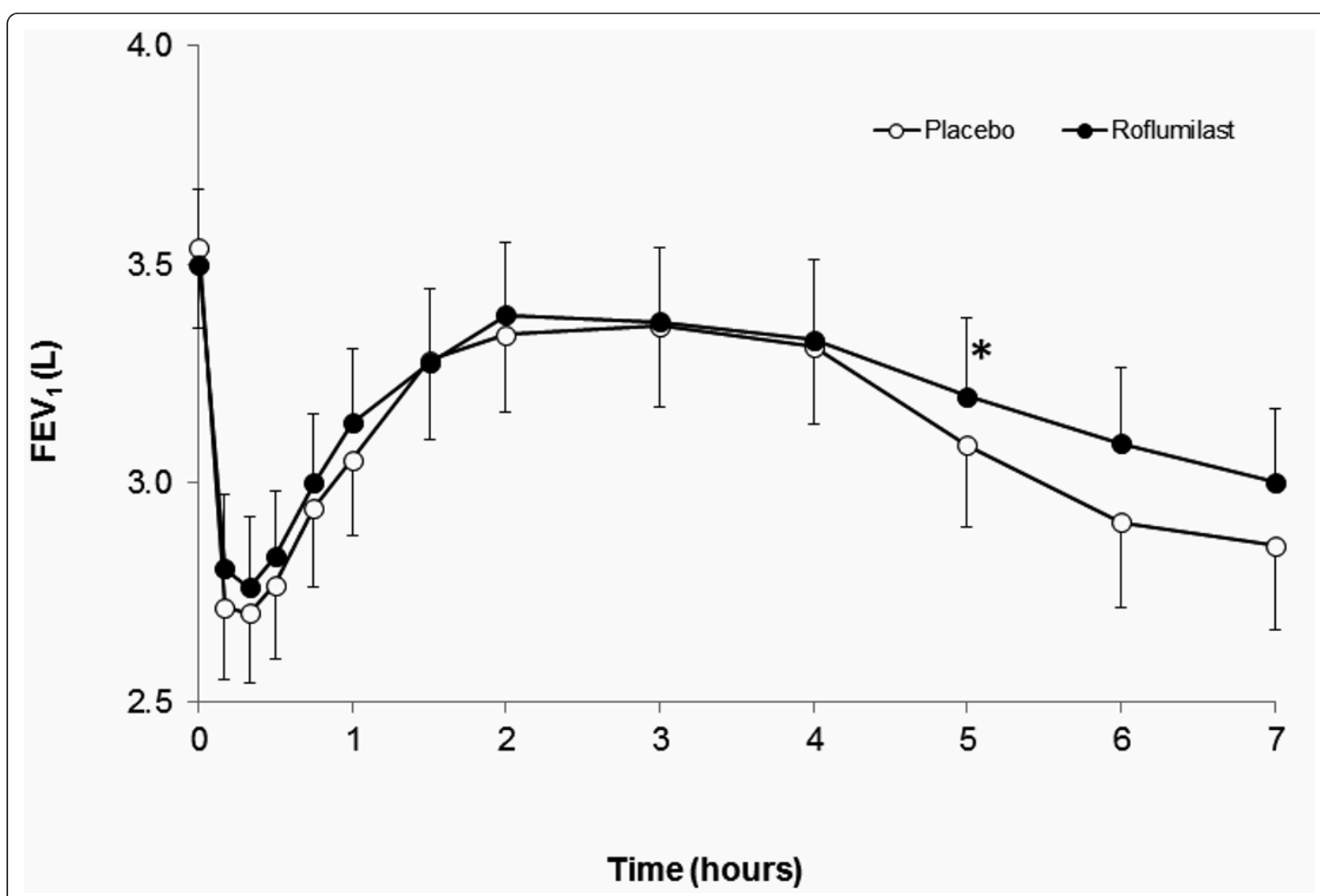

Figure 4 Mean percent fall in $\mathrm{FEV}_{1}( \pm \mathrm{SEM})$ during the early and late asthmatic responses. Roflumilast significantly inhibited the area of the early and late responses $(p<0.05)$. FEV1: forced expiratory volume in 1 second.

\section{Airway Hyperresponsiveness}

The methacholine $\mathrm{PC}_{20}$ was unchanged following 13 days' treatment with placebo or roflumilast $(\mathrm{p}>0.05)$, and fell significantly $24 \mathrm{~h}$ post-allergen with both placebo and roflumilast ( $\mathrm{p}=0.022$ and $<0.0001$, respectively). However, roflumilast significantly attenuated the allergen-induced fall in AHR from 5.64 $\pm 1.26 \mathrm{mg} /$ $\mathrm{mL}$ pre-allergen to $3.65 \pm 0.81 \mathrm{mg} / \mathrm{mL} 24 \mathrm{~h}$ post-allergen, compared to placebo from $5.39 \pm 1.18 \mathrm{mg} / \mathrm{mL}$ pre-allergen to $1.80 \pm 0.42 \mathrm{mg} / \mathrm{mL} 24 \mathrm{~h}$ post-allergen $(\mathrm{p}=0.004)$.

\section{Safety}

One subject under treatment with roflumilast experienced a serious adverse event of depression and was withdrawn from the study. This subject did not have a history of depression. Headache was the most frequently reported adverse event (AE) with roflumilast treatment (4 roflumilast versus 0 placebo), followed by nausea ( 2 roflumilast versus 0 placebo). The majority of AEs were not considered related to study medication. There were no significant differences between treatments in median values of hematology and blood chemistry variables.

\section{Pharmacokinetics in Plasma}

Pharmacokinetic profiles were obtained from 15 subjects at Day 14. Following repeated oral doses of roflumilast, estimates of roflumilast and the active metabolite $\mathrm{N}$-oxide roflumilast at Day 14 show maximum plasma concentrations of $7.04 \pm 0.65 \mathrm{mcg} / \mathrm{L}$ and $26.8 \pm 2.59$ $\mathrm{mcg} / \mathrm{L}$ reached at $1.83 \pm 0.27 \mathrm{~h}$ and $4.37 \pm 0.5 \mathrm{~h}$, respectively (Figure 5 ). The pharmacokinetic profiles and estimates of roflumilast and roflumilast $\mathrm{N}$-oxide are similar to those in previous pharmacokinetic studies in healthy volunteers [28].

\section{Discussion}

The orally active PDE4 inhibitors roflumilast and CDP840, given either as a single dose or regularly are known to inhibit the allergen-induced LAR and AHR [29-31], and rolfumilast has been shown to reduce sputum eosinophil and neutrophils in subjects with COPD [32]. We hypothesized that oral roflumilast would also attenuate allergen-induced airway inflammation, including neutrophilia, which is not generally a target for asthma treatment asthma [3]. This study examined the safety of 14 days' oral treatment with roflumilast $500 \mathrm{mcg}$ 


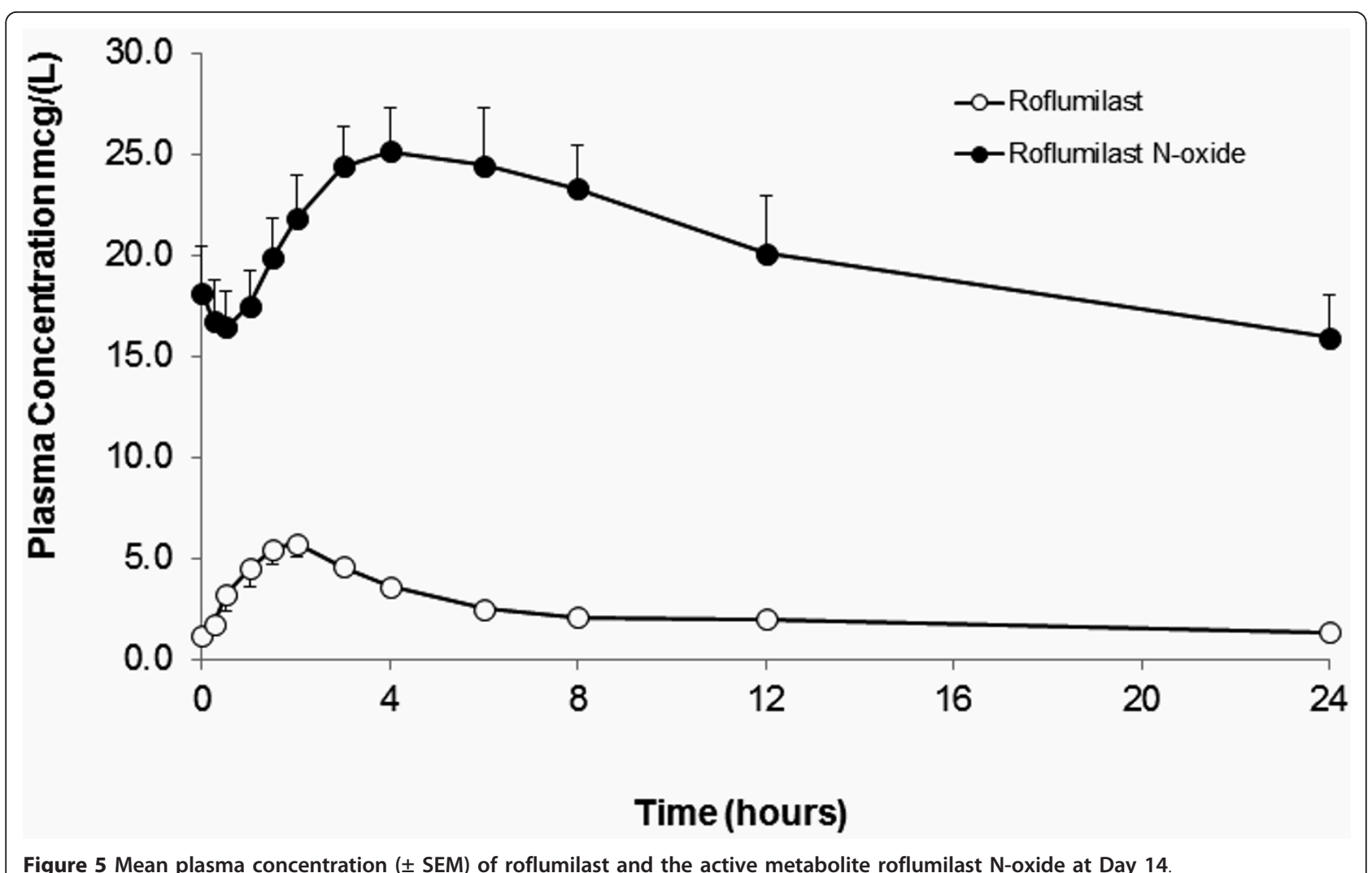

in patients with mild asthma and its effects on allergeninduced airway inflammation. The results show that roflumilast attenuated allergen-induced accumulation of inflammatory cells and inflammatory mediators.

In asthma, there is an increase in the number of inflammatory cells within the airways. It is believed that through the release of their mediators and enzymes [4-6] these effector cells contribute to the persistence of inflammation, AHR and increased bronchial tone [1-3]. Roflumilast is a selective PDE4 inhibitor, this inhibition leads to increased cAMP levels in inflammatory cells, rendering them less likely to respond to stimuli. Thus, cell functions, including chemotaxis, survival and activation, which are mediated through cAMP, will be impaired with roflumilast treatment. Roflumilast has been shown to block inflammatory cell influx through inhibition of Pand E-selectin expression on endothelial cells, and CD11b expression on neutrophils [33], and blocks the release of various inflammatory mediators including TNF-alpha, LTB $_{4}$, IL-4 and IL-5 [34]. In keeping with the proposed broad anti-inflammatory effects of roflumilast, the allergen-induced increase in eosinophils, neutrophils, MCC and total leukocyte counts in sputum were inhibited with active treatment. This inhibitory effect on inflammatory cell numbers was also observed in the sputum of subjects with COPD where $500 \mathrm{mcg}$ roflumilast once daily for 4 weeks decreased the total cell count [32].

We hypothesized that roflumilast would suppress the migration and activation of cells involved in the allergic immune response in the airways following allergen inhalation challenge, and thus reduce the physiological responses of EAR, LAR and AHR. This study demonstrates that roflumilast attenuates allergen-induced physiologic responses in subjects with mild allergic asthma, albeit the effect is small as compared to inhaled corticosteroids [35]. Inhibition of physiologic responses is coincident with a larger inhibition of airway inflammation, especially the neutrophil population. Airway neutrophilia has been shown to be elevated in severe asthma, however this could be due, in part, to inhaled corticosteroid treatment [36]. As such, the role of the neutrophil in asthma is still uncertain. Mast cells and basophils are positioned to play a major role in the development of the EAR following IgE-dependent release of histamine and cysteinyl leukotrienes. Inhibition of activation of MCC in sputum by inhaled allergen provides one mechanism for inhibition of the EAR by roflumilast. Likewise, reduced accumulation of eosinophils, neutrophils and their mediators in the airways post allergen reduces inflammatory signals 
that contribute to development of the LAR. Inhibition of allergen-induced EAR and LAR and AHR is unlikely to be mediated through smooth muscle relaxation because we did not observe improvements in $\mathrm{FEV}_{1}$ post-dosing consistent with the lack of direct bronchodilatory activity [37].

\section{Conclusions}

This is the first study to demonstrate inhibition of both allergen-induced airway eosinophilia and neutrophilia with pharmacological intervention, and suggests that the broad anti-inflammatory properties of roflumilast may be effective in attenuating the airway neutrophilic inflammation, which is not well-controlled by corticosteroids.

\section{List of abbreviations}

AE: adverse event; AHR: airway hyperresponsiveness; AUC: area under the curve; CAMP: cyclic adenosine monophosphate; cGMP: cyclic guanosine monophosphate; COPD: chronic obstructive pulmonary disease; EAR: early asthmatic response; ECP: eosinophil cationic protein; $\mathrm{FEV}_{1}$ : forced expiratory volume in one second; IL: interleukin; LAR: late asthmatic response; MCC: metachromatic cells; $\mathrm{PC}_{20}$ : The provocative concentration of methacholine causing a $20 \%$ fall in $\mathrm{FEV}_{1}$; PDE4: phosphodiesterase 4; PK: pharmacokinetics; SEM: standard error of the mean.

\section{Acknowledgements}

The authors wish to acknowledge NYCOMED GmbH for funding the study. The authors would like to acknowledge Dr Frank Cerasoli and Dr Theodore Lee for their contributions to the protocol and interpretation of the data.

\section{Author details}

${ }^{1}$ Department of Medicine, McMaster University, Hamilton, Ontario, Canada. ${ }^{2}$ Institut Universitaire de Cardiologie et de Pneumologie de Québec, Quebec City, Quebec, Canada. ${ }^{3}$ NYCOMED GmbH, Konstanz, Germany.

\section{Authors' contributions}

GMG and PO'B designed the study and together with CS, DB and L-PB wrote the manuscript. JC, KJK and MD were responsible for medical procedures. RW, FD, JM, and TS performed study analyses. All authors read and approved the final manuscript.

\section{Competing interests}

This study was funded by NYCOMED. CSW and DB are employees of NYCOMED. The remaining authors have no conflict of interest to declare.

Received: 1 September 2011 Accepted: 26 October 2011

Published: 26 October 2011

\section{References}

1. Fahy JV, Wong H, Liu J, Boushey HA: Comparison of samples collected by sputum induction and bronchoscopy from asthmatic and healthy subjects. Am J Respir Crit Care Med 1995, 152:53-8.

2. Shannon J, Ernst P, Yamauchi Y, Olivenstein R, Lemiere C, Foley S, Cicora L, Ludwig M, Hamid Q, Martin JG: Differences in airway cytokine profile in severe asthma compared to moderate asthma. Chest 2008, 133:420-426.

3. Qiu Y, Zhu J, Bandi V, Guntupalli KK, Jeffery PK: Bronchial mucosal inflammation and upregulation of CXC chemoattractants and receptors in severe exacerbations of asthma. Thorax 2007, 62:475-482.

4. Keatings VM, Jatakanon A, Worsdell YM, Barnes PJ: Effects of inhaled and oral glucocorticoids on inflammatory indices in asthma and COPD. Am J Respir Crit Care Med 1997, 155:542-548.

5. Nguyen LT, Lim S, Oates T, Chung KF: Increase in airway neutrophils after oral but not inhaled corticosteroid therapy in mild asthma. Respir Med 2005, 99:200-207.
6. Schudt C, Gantner F, Tenors H, Hatzelmann A: Therapeutic potential of selective PDE inhibitors in asthma. Pulm Pharmacol Ther 1999, 12:123-129.

7. Beavo JA: Cyclic nucleotide phosphodiesterases: functional implications of multiple isoforms. Physiol Rev 1995, 75:725-748.

8. Calverley PM, Rabe KF, Goehring UM, Kristiansen S, Fabbri LM, Martinez FJ M2-124 and M2-125 study groups: Roflumilast in symptomatic chronic obstructive pulmonary disease: two randomised clinical trials. Lancet 2009, 374:685-694.

9. Fabbri LM, Calverley PM, Izquierdo-Alonso JL, Bundschuh DS, Brose M, Martinez FJ, Rabe KF, M2-127 and M2-128 study groups: Roflumilast in moderate-to-severe chronic obstructive pulmonary disease treated with longacting bronchodilators: two randomised clinical trials. Lancet 2009, 374:695-703.

10. Pryzwansky KB, Madden VJ: Type 4A cAMP-specific phosphodiesterase is stored in granules of human neutrophils and eosinophils. Cell Tissue Res 2003, 312:301-311.

11. Peter D, Jin SL, Conti M, Hatzelmann A, Zitt C: Differential expression and function of phosphodiesterase 4 (PDE4) subtypes in human primary CD4 + T cells: predominant role of PDE4. J Immunol 2007, 178:4820-4831.

12. Sawai T, Ikai K, Uehara M: Cyclic adenosine monophosphate phosphodiesterase activity in peripheral blood mononuclear leucocytes from patients with atopic dermatitis: correlation with respiratory atopy. Br J Dermatol 1998, 138:846-848.

13. Hanifin JM, Chan SC: Monocyte phosphodiesterase abnormalities and dysregulation of lymphocyte function in atopic dermatitis. J Invest Dermatol 1995, 105(1 Suppl):84S-8S

14. Hatzelmann A, Morcillo EJ, Lungarella G, Adnot S, Sanjar S, Beume R, Schudt C, Tenor H: The preclinical pharmacology of roflumilast-a selective, oral phosphodiesterase 4 inhibitor in development for chronic obstructive pulmonary disease. Pulm Pharmacol Ther 2010, 23:235-256.

15. Boulet LP, Gauvreau G, Boulay ME, O'Byrne P, Cockcroft DW: The allergen bronchoprovocation model: an important tool for the investigation of new asthma anti-inflammatory therapies. Allergy 2007, 62:1101-1110.

16. O'Byrne PM, Dolovich J, Hargreave FE: Late asthmatic responses. Am Rev Respir Dis 1987, 136:740-751.

17. Gauvreau GM, Lee JM, Watson RM, Irani AM, Schwartz LB, O'Byrne PM: Increased numbers of both airway basophils and mast cells in sputum after allergen inhalation challenge of atopic asthmatics. Am J Respir Crit Care Med 2000, 161:1473-1478.

18. Gauvreau GM, Watson RM, O'Byrne PM: Kinetics of allergen-induced airway eosinophilic cytokine production and airway inflammation. Am J Respir Crit Care Med 1999, 160:640-647.

19. Aalbers R, Kauffman HF, Vrugt B, Koeter GH, de Monchy JG: Allergeninduced recruitment of inflammatory cells in lavage 3 and $24 \mathrm{~h}$ after challenge in allergic asthmatic lungs. Chest 1993, 103:1178-1184.

20. Woolley $\mathrm{KL}$, Adelroth $\mathrm{E}$, Woolley MJ, Ellis R, Jordana M, O'Byrne PM: Effects of allergen challenge on eosinophils, eosinophil cationic protein, and granulocyte-macrophage colony-stimulating factor in mild asthma. Am J Respir Crit Care Med 1995, 151:1915-1924.

21. Bentley AM, Meng Q, Robinson DS, Hamid Q, Kay AB, Durham SR: Increases in activated T lymphocytes, eosinophils, and cytokine mRNA expression for interleukin-5 and granulocyte/macrophage colony-stimulating factor in bronchial biopsies after allergen inhalation challenge in atopic asthmatics. Am J Respir Cell Mol Biol 1993, 8:35-42.

22. Nouri-Aria KT, Irani AM, Jacobson MR, O'brien F, Varga EM, Till SJ, Durham SR, Schwartz LB: Basophil recruitment and IL-4 production during human allergen-induced late asthma. J Allergy Clin Immunol 2001, 108:205-211.

23. Gauvreau GM, Boulet LP, Cote J, Deschesnes F, Duong M, Killian K, Obminski G, Strinich TX, Watson RM, Cerasoli F, Schmid-Wirlitsch C, Bredenbröker D, O'Byrne PM: Effects of roflumilast on airway inflammation and function following allergen challenge in patients with allergic asthma [abstract]. Am J Respir Crit Care Med 2007, 175:A484.

24. Bateman ED, Izquierdo JL, Harnest U, Hofbauer P, Magyar P, SchmidWirlitsch C, Leichtl S, Bredenbröker D: Efficacy and safety of roflumilast in the treatment of asthma. Ann Allergy Asthma Immunol 2006, 96:679-686.

25. Cockcroft DW: Measure of airway responsiveness to inhaled histamine or methacholine; method of continuous aerosol generation and tidal breathing inhalation. In Airway responsiveness: measurement and 
interpretation. Edited by: Hargreave FE, Woolcock AJ. Mississauga: Astra Pharmaceuticals Canada Ltd; 1985:22-28.

26. Cockcroft DW, Murdock KY, Kirby J, Hargreave F: Prediction of airway responsiveness to allergen from skin sensitivity to allergen and airway responsiveness to histamine. Am Rev Respir Dis 1987, 135:264-267.

27. Pizzichini E, Pizzichini MM, Efthimiadis A, Evans S, Morris MM, Squillace D, Gleich GJ, Dolovich J, Hargreave FE: Indices of airway inflammation in induced sputum: reproducibility and validity of cell and fluid-phase measurements. Am J Respir Crit Care Med 1996, 154:308-317.

28. Bethke TD, Giessmann T, Westphal K, Weinbrenner A, Hauns B, Hauschke D, David M, Lahu G, Zech K, Hermann R, Siegmund W: Roflumilast, a oncedaily oral phosphodiesterase 4 inhibitor, lacks relevant pharmacokinetic interactions with inhaled salbutamol when co-administered in healthy subjects. Int J Clin Pharmacol Ther 2006, 44:572-579.

29. Harbinson PL, MacLeod D, Hawksworth R, OToole S, Sullivan PJ, Heath P, Kiffeather S, Page CP, Costello J, Holgate ST, Lee TH: The effect of a novel orally active selective PDE4 isoenzyme inhibitor (CDP840) on allergeninduced responses in asthmatic subjects. Eur Respir J 1997, 10:1008-1014.

30. Louw C, Williams Z, Venter L, Leichtl S, Schmid-Wirlitsch C, Bredenbroker D, Bardin PG: Roflumilast, a phosphodiesterase 4 inhibitor, reduces airway hyperresponsiveness after allergen challenge. Respiration 2007, 74:411-417.

31. van Schalkwyk E, Strydom K, Williams Z, Venter L, Leichtl S, SchmidWirlitsch C, Bredenbröker D, Bardin PG: Roflumilast, an oral, once-daily phosphodiesterase 4 inhibitor, attenuates allergen-induced asthmatic reactions. J Allergy Clin Immunol 2005, 116:292-298.

32. Grootendorst DC, Gauw SA, Verhoosel RM, Sterk PJ, Hospers J J Bredenbroker D, Bethke TD, Hiemstra PS, Rabe KF: Reduction in sputum neutrophil and eosinophil numbers by the PDE4 inhibitor roflumilast in patients with COPD. Thorax 2007, 62:1081-1087.

33. Sanz MJ, Cortijo J, Taha MA, Cerda-Nicolas M, Schatton E, Burgbacher B, Klar J, Tenor H, Schudt C, Issekutz AC, Hatzelmann A, Morcillo EJ: Roflumilast inhibits leukocyte-endothelial cell interactions, expression of adhesion molecules and microvascular permeability. Br J Pharmacol 2007, 152:481-492.

34. Hatzelmann A, Schudt C: Anti-inflammatory and immunomodulatory potential of the novel PDE4 inhibitor roflumilast in vitro. J Pharmacol Exp Ther 2001, 297:267-279.

35. Gauvreau GM, Doctor J, Watron R, Jordana M, O'Byrne PM: Effects of inhaled budesonide on allergen-induced airway responses and airway inflammation. Am J Respir Crit Care Med 1996, 154:1267-1271.

36. Cowan DC, Cowan JO, Palmay R, Williamson A, Taylor DR: Effects of steroid therapy on inflammatory cell subtypes in asthma. Thorax 2010, 65:384-390.

37. Grootendorst DC, Gauw SA, Baan R, Kelly J, Murdoch RD, Sterk PJ, Rabe KF: Does a single dose of the phosphodiesterase 4 inhibitor, cilomilast (15 $\mathrm{mg}$ ), induce bronchodilation in patients with chronic obstructive pulmonary disease? Pulm Pharmacol Ther 2003, 16:115-120.

doi:10.1186/1465-9921-12-140

Cite this article as: Gauvreau et al: Roflumilast attenuates allergeninduced inflammation in mild asthmatic subjects. Respiratory Research 2011 12:140

\section{Submit your next manuscript to BioMed Central and take full advantage of:}

- Convenient online submission

- Thorough peer review

- No space constraints or color figure charges

- Immediate publication on acceptance

- Inclusion in PubMed, CAS, Scopus and Google Scholar

- Research which is freely available for redistribution 